\title{
Peroxisomal Enzymes in the Liver of Rats With Experimental Diabetes Mellitus Type 2
}

\author{
L. TURECKÝ ${ }^{1}$, V. KUPČOVÁ ${ }^{2}$, E. UHLÍKOVÁ ${ }^{1}$, V. MOJTO ${ }^{2}$ \\ ${ }^{1}$ Institute of Medical Chemistry, Biochemistry and Clinical Biochemistry, Medical School, \\ Comenius University, Bratislava, Slovak Republic, ${ }^{2}$ Third Department of Internal Medicine, \\ Medical School, Comenius University, Bratislava, Slovak Republic
}

Received March 12, 2014

Accepted August 18, 2014

\section{Summary}

Diabetes mellitus is relatively frequently associated with fatty liver disease. Increased oxidative stress probably plays an important role in the development of this hepatopathy. One of possible sources of reactive oxygen species in liver is peroxisomal system. There are several reports about changes of peroxisomal enzymes in experimental diabetes, mainly enzymes of fatty acid oxidation. The aim of our study was to investigate the possible changes of activities of liver peroxisomal enzymes, other than enzymes of beta-oxidation, in experimental diabetes mellitus type 2. Biochemical changes in liver of experimental animals suggest the presence of liver steatosis. The changes of serum parameters in experimental group are similar to changes in serum of patients with non-alcoholic fatty liver disease. We have shown that diabetes mellitus influenced peroxisomal enzymes by the different way. Despite of well-known induction of peroxisomal beta-oxidation, the activities of catalase, aminoacid oxidase and $\mathrm{NADH}$-cytochrome $b_{5}$ reductase were not significantly changed and the activities of glycolate oxidase and NADP-isocitrate dehydrogenase were significantly decreased. The effect of diabetes on liver peroxisomes is probably due to the increased supply of fatty acids to liver in diabetic state and also due to increased oxidative stress. The changes of metabolic activity of peroxisomal compartment may participate on the development of diabetic hepatopathy.
\end{abstract}

\section{Key words}

Peroxisomes • Diabetes mellitus • Oxidative stress • Fatty liver disease

\section{Corresponding author}

L. Turecky, Institute of Medical Chemistry, Biochemistry and Clinical Biochemistry, Medical School, Comenius University,
Sasinkova 2, 81108 Bratislava, Slovak Republic. E-mail: ladislav.turecky@fmed.uniba.sk

\section{Introduction}

Diabetes mellitus is a metabolic disease which is relatively frequent connected with development of simple steatosis or steatohepatitis. Increased oxidative stress and lipoperoxidation probably play an important role in the development of these hepatopathies. One of possible sources of reactive oxygen species in liver tissue is peroxisomal system.

Peroxisomes are the special type of subcellular structures characterized by containing hydrogen peroxide producing oxidases and by simultaneous content of catalase which is able to degrade or utilize $\mathrm{H}_{2} \mathrm{O}_{2}$ in oxidation-reduction reactions (Chandoga 1994). Their great variability of enzyme content and prompt regulation of genome expression in dependence on nutritional conditions make from these organelles the significant cellular metabolic compartment.

There are several reports about changes of peroxisomal enzymes in experimental diabetes mellitus, mainly enzymes of fatty acid oxidation (Thomas et al. 1989, Engels et al. 1999, Asayama et al. 1999).

The aim of our study was to investigate the possible changes of activities of liver peroxisomal enzymes, other than enzymes of beta-oxidation, in experimental streptozotocin diabetes mellitus induced in newborn animals, which is accepted as model of diabetes mellitus type 2 (Iwase 1991, Derkach et al. 2013, Sharma et al. 2013). 


\section{Materials and Methods}

Chemicals

We purchased streptozotocin from Calbiochem (Los Angeles, CA, USA). All other used chemicals were of the highest grade available and were purchased from Sigma-Aldrich (St. Louis, MO, USA).

\section{Animal experiments}

Newborn male Wistar rats were used in the experiment. Diabetes mellitus was induced by repeated intraperitoneal administration of streptozotocin $(45 \mathrm{mg} / \mathrm{kg}$ body weight in 0.1 mol. $1^{-1}$ citrate buffer, $\mathrm{pH}=4.5$ ) on $2^{\text {nd }}$ and $9^{\text {th }}$ day after birth. Control group received only the same volume of citrate buffer at the same time. Young rats were with mother till $24^{\text {th }}$ day after birth. After this time they were alone and had free access to water and defined diet (Larsen diet, TOP DOVO, Dobrá Voda, Slovak Republic) and were kept at constant temperature under constant light-dark cycle. All animal experimentation was approved by the local Ethical Committee and complied with the "Principles of laboratory animal care" (NIH publication no.85-23, revised 1985).

\section{Tissue preparation}

12 weeks after birth the animals were killed by decapitation at constant time of day. The livers were perfused with ice-cold homogenization buffer (10 mmol. ${ }^{-1}$ TRIS/HCl, $\mathrm{pH}=7.4$, containing 0.25 mol. $\mathrm{l}^{-1}$ sucrose and 1 mmol. $1^{-1}$ Na-EDTA), minced and homogenized using Ultra-Turrax to give $10 \%(\mathrm{w} / \mathrm{v})$ homogenate. The blood was collected immediately after decapitation. After coagulation for $30 \mathrm{~min}$ at room temperature the serum was obtained by centrifugation for
$5 \mathrm{~min}$ at $3000 \mathrm{~g}$.

\section{Biochemical analyses}

Glucose, triacylglycerols and cholesterol levels and cholinesterase, alanine aminotransferase and aspartate aminotransferase activities were determined using commercial kits (DOT Diagnostics, s.r.o. Praha, Czech Republic and PLIVA-LACHEMA a.s., Brno, Czech Republic) as recommended by the manufacturers. Fructosamine was determined according to Johnson et al. (1982). Proteins were determined by the method of Lowry et al. (1951), using bovine serum albumin as a standard and glycogen with anthrone solution (Niederland et al. 1956). Catalase (EC 1.11.1.6.) activity was determined according to Sinha (1972). For detection of L-hydroxy acid oxidase (EC 1.1.3.1., GOX) activity the reaction product - glyoxylate was determined by coupling with 2,4-dinitrophenylhydrazine. D-amino acid oxidase (EC 1.4.3.3., DAOX) was assayed spectrophotometrically using D-alanine as substrate (Baudhuin et al. 1964). NADH-cytochrome $b_{5}$ reductase (EC 1.6.2.2.) activity was determined photometrically according to the method of Mihara and Sato (1978), activity of NADP-dependent isocitrate dehydrogenase (EC 1.1.1.42., ICDH) was determined with UV-kinetic method according to Bernt and Bergmeyer (1974). The activity of lipoperoxidation was determined according to methods of Devasagayam (1986) and Devasagayam and Tarachand (1988).

\section{Statistical analysis}

Statistical analysis was performed using the nonparametric Wilcoxon test included in Statgraphics program. Data are given as means \pm SEM. We considered $p$ values of less than 0.05 to be statistically significant.

Table 1. Blood serum parameters of control and diabetic rats.

\begin{tabular}{|c|c|c|c|c|c|c|}
\hline & $\begin{array}{c}\text { Glycaemia } \\
\text { mmol. }^{-1}\end{array}$ & $\begin{array}{l}\text { Fructosamine } \\
\text { mmol. }^{-1}\end{array}$ & $\begin{array}{c}\text { Cholesterol } \\
\text { mmol. }^{-1}\end{array}$ & $\begin{array}{c}\text { Triacylglycerols } \\
\text { mmol. }^{-1}\end{array}$ & 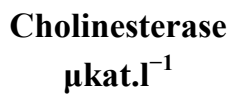 & $\begin{array}{c}\text { ALT } \\
\text { Hkat.l }^{-1}\end{array}$ \\
\hline Controls & $7.60 \pm 0.50$ & $0.82 \pm 0.08$ & $1.95 \pm 0.22$ & $1.25 \pm 0.31$ & $4.92 \pm 0.51$ & $1.05 \pm 0.09$ \\
\hline $\begin{array}{l}\text { Diabetes } \\
\text { mellitus }\end{array}$ & $28.20 \pm 2.14$ & $1.71 \pm 0.22$ & $3.02 \pm 0.32$ & $2.42 \pm 0.31$ & $15.31 \pm 2.31$ & $1.48 \pm 0.12$ \\
\hline $\begin{array}{l}\text { Statistical } \\
\text { significance }\end{array}$ & $\mathrm{P}<0.001$ & $\mathrm{P}<0.001$ & $\mathrm{P}<0.01$ & $\mathrm{P}<0.001$ & $\mathrm{P}<0.001$ & $\mathrm{P}<0.01$ \\
\hline
\end{tabular}

Results are given as mean \pm SEM, each group consists of 8 animals $(n=8)$. 
Table 2. Basic components of liver tissue of control and diabetic animals.

\begin{tabular}{lcccc}
\hline & $\begin{array}{c}\text { Glycogen } \\
\mathbf{m g . g}^{-1} \text { tissue }\end{array}$ & $\begin{array}{c}\text { Cholesterol } \\
\boldsymbol{\mu m o l . g ^ { - 1 }} \text { tissue }\end{array}$ & $\begin{array}{c}\text { Triacylglycerols } \\
\boldsymbol{\mu m o l . g}^{-1} \text { tissue }\end{array}$ & $\begin{array}{c}\text { Proteins } \\
\mathbf{m g . g}^{-1} \text { tissue }^{-}\end{array}$ \\
\hline Controls & $70.80 \pm 6.32$ & $7.21 \pm 0.65$ & $7.91 \pm 0.62$ & $178.60 \pm 16.51$ \\
Diabetes mellitus & $39.22 \pm 4.54$ & $7.32 \pm 0.82$ & $10.33 \pm 0.85$ & $222.85 \pm 23.54$ \\
Statistical significance & $\mathrm{P}<0.01$ & N.S. & $\mathrm{P}<0.05$ & $\mathrm{P}<0.01$ \\
\hline
\end{tabular}

Results are given as mean \pm SEM, N.S. - not significant, each group consists of 8 animals $(n=8)$.

Table 3. Activity of lipoperoxidation in liver tissue of control and diabetic animals.

\begin{tabular}{lcc}
\hline & $\begin{array}{c}\text { Non-stimulated lipoperoxidation } \\
\text { pg.g }^{-1} \cdot \mathbf{m i n}^{-\mathbf{1}}\end{array}$ & $\begin{array}{c}\text { Stimulated lipoperoxidation } \\
\mathbf{n g . g}^{-1} \cdot \mathbf{m i n}^{-\mathbf{1}}\end{array}$ \\
\hline Controls & $1.24 \pm 0.11$ & $0.783 \pm 0.063$ \\
Diabetes mellitus & $1.62 \pm 0.18$ & $1.350 \pm 0.143$ \\
Statistical significance & $\mathrm{P}<0.05$ & $\mathrm{P}<0.001$ \\
\hline
\end{tabular}

Results are given as ng or pg of malondialdehyde produced per $1 \mathrm{~min}$ in $1 \mathrm{~g}$ of liver tissue.

\section{Results}

Treatment of newborn rats with two injections of streptozotocin resulted in induction of diabetes mellitus. The animals were killed 12 weeks after birth. The blood glucose was increased 4-fold from $7.6 \pm 0.5 \mathrm{mmol}^{-1}$ to 28.4 \pm 2.1 mmol. $1^{-1}$ (Table 1). Plasma lipids triacylglycerols and cholesterol - were significantly increased in blood of diabetic animals. The activities of plasma cholinesterase $\left(4.92 \pm 0.51\right.$ vs. $15.31 \pm 2.31 \mu \mathrm{kat}^{-1}{ }^{-1}$, $\mathrm{P}<0.001)$ and alanine aminotransferase $(1.05 \pm 0.09$ vs. $\left.1.48 \pm 0.12 \mu \mathrm{kat}^{-1} \mathrm{l}^{-1}, \mathrm{P}<0.01\right)$ were in diabetic animals significantly increased in comparison with controls. The activity of aspartate aminotransferase was not significantly changed in comparison to control animals. The body weight of streptozotocin-diabetic animals showed loss of $20 \%$. There was also slight decrease in liver weight of diabetic animals (from $14.55 \pm 1.05 \mathrm{~g}$ in controls to $13.29 \pm 1.43 \mathrm{~g}$ in diabetic animals) but this change was not statistically significant. The liver/body weight ratio showed significant increase in diabetic animals in comparison with controls $(3.78 \pm 0.15$ in controls to $4.49 \pm 0.37, \quad \mathrm{P}<0.05)$ which suggests the relative increasing of liver in diabetic animals.

Determination of basic components of liver tissue showed significant decreased content of glycogen in liver of diabetic rats in comparison with healthy controls (Table 2). The content of cholesterol was not significantly different between experimental and control group, but the content of triacylglycerols was significantly increased in liver of experimental rats. The determination of proteins in liver tissue showed slight but significant increase in content of proteins in diabetic animals (178.6 $\pm 16.5 \mathrm{mg} . \mathrm{g}^{-1}$ tissue vs. $222.8 \pm 23.5 \mathrm{mg} . \mathrm{g}^{-1}$ tissue).

The results of analysis of lipid peroxidation are shown in Table 3. In studying of activity of lipoperoxidation in liver tissue in vitro, we determined non-stimulated and also stimulated lipid peroxidation (stimulation with mixture of ascorbic acid and $\mathrm{FeSO}_{4}$ ). There was $40 \%$ increase in activity of non-stimulated lipid peroxidation and $70 \%$ increase in activity of stimulated lipid peroxidation in diabetic animals $(\mathrm{P}<0.01)$ in comparison with control group.

Peroxisomal enzyme activities observed in rats with experimental diabetes mellitus are presented in Table 4. Diabetes caused a $35 \%$ loss in activity of liver L-hydroxy acid oxidase and $60 \%$ loss in activity of NADP-ICDH. These changes were statistically significant $(\mathrm{P}<0.01)$. There was also slight decrease of activities of catalase and $\mathrm{NADH}$-cytochrome $\mathrm{b}_{5}$ reductase, but these changes were not significant. Activity of liver D-amino acid oxidase was not statistically different in diabetic rats in comparison with control group. 
Table 4. Activities of peroxisomal enzymes in liver tissue of control and diabetic animals.

\begin{tabular}{|c|c|c|c|c|c|}
\hline & $\begin{array}{c}\text { Catalase } \\
\text { mkat.g }^{-1} \text { tissue }\end{array}$ & $\begin{array}{c}\text { GOX } \\
\text { nkat.g }{ }^{-1} \text { tissue }\end{array}$ & $\begin{array}{l}\text { NADP-ICDH } \\
\text { nkat.g }^{-1} \text { tissue }\end{array}$ & $\begin{array}{c}\text { DAOX } \\
\text { nkat.g }^{-1} \text { tissue }\end{array}$ & $\begin{array}{c}\text { NADH-cytochrome } \\
\text { b }_{5} \text { reductase } \\
\text { nkat.g }^{-1} \text { tissue }\end{array}$ \\
\hline Controls & $2.53 \pm 0.28$ & $18.57 \pm 1.94$ & $228 \pm 25$ & $7.05 \pm 0.82$ & $360.0 \pm 29$ \\
\hline $\begin{array}{l}\text { Diabetes } \\
\text { mellitus }\end{array}$ & $2.26 \pm 0.29$ & $12.15 \pm 1.51$ & $95 \pm 14$ & $8.21 \pm 0.92$ & $323.0 \pm 57$ \\
\hline $\begin{array}{l}\text { Statistical } \\
\text { significance }\end{array}$ & N.S. & $\mathrm{P}<0.01$ & $\mathrm{P}<0.001$ & N.S. & N.S. \\
\hline
\end{tabular}

Results are given as mean \pm SEM, N.S. - not significant, each group consists of 8 animals $(n=8)$. GOX - glycolate oxidase, DAOX D-amino acid oxidase, ICDH - isocitrate dehydrogenase

\section{Discussion}

In the human pathology it is mainly diabetes mellitus type 2 which is associated with the development of fatty liver disease. Streptozotocin diabetes mellitus induced in newborn rats is accepted as a model of type 2 diabetes mellitus (Portha et al. 1988, Islam and Loots 2009, Kaya-Dagistanli and Ozturk 2013). Biochemical changes which were found in liver of experimental animals (increased content of triacylglycerols in liver tissue) suggest the presence of liver steatosis in animals with experimental streptozotocin diabetes mellitus. The changes of serum parameters in experimental group, such as increased levels of triacylglycerols and cholesterol, increased activities of serum cholinesterase and alanine aminotransferase are very similar to changes which are present in serum of patients with non-alcoholic fatty liver disease or non-alcoholic steatohepatitis (James 2000, Turecký et al. 2005). It seems that experimental streptozotocin diabetes mellitus induced in newborn rats is an adequate model for diabetic fatty liver disease.

The precise pathogenesis of non-alcoholic fatty liver disease (NAFLD) is unknown. NAFLD is strongly associated with obesity and type 2 diabetes (Marchesini et al. 1999, Matteoni et al. 1999, Diehl 2000). Moreover obesity and diabetes have been identified as independent risk factors for histologically advanced NAFLD. Together these findings suggest that some of the metabolic and/or hormonal alterations that occur in obesity and/or diabetes might promote NAFLD. It exists hypothesis which characterizes NASH as a disease of two "hits", the first "hit" being the development of fatty liver increasing the sensitivity of the liver to the second "hit" of oxidation stress, endotoxin and ischemia (Day and James 1998). The state of oxidative stress occurs when the balance of production of reactive oxygen species and its metabolites exceeds the capacity to defend against or detoxify them. The consequent exposure to hydrogen peroxide $\left(\mathrm{H}_{2} \mathrm{O}_{2}\right)$ and hydroxyl radical can damage macromolecules, including lipids, DNA and proteins. The presence of increased oxidative stress was confirmed also in our experimental group of animals with streptozotocin diabetes. There were found increased activity of basal and stimulated lipoperoxidation in liver tissue of diabetic animals in comparison to control group.

One of the potential sources of ROS in liver of diabetic animals is peroxisomal system. Peroxisomes represent a class of ubiquitous and essential singlemembrane bound cell organelles which play a critical role in a variety of metabolic processes including fatty acid oxidation, ether phospholipid biosynthesis, peroxide and ROS metabolism, glyoxylate cleaning, catabolism of purines, polyamines, prostaglandins and eicosanoids, and possibly the biosynthesis of isoprenoids (Delille et al. 2006). Peroxisomes generate significant amount of hydrogen peroxide (about $35 \%$ of all $\mathrm{H}_{2} \mathrm{O}_{2}$ produced in rat liver) through the action of several peroxisomal oxidases that can be converted to more aggressive ROS (Boveris et al. 1972).

In the literature there are several reports concerned with the effect of diabetes on liver peroxisomes. The most of these papers described the effect of diabetes mellitus on peroxisomal beta-oxidation (Thomas et al. 1989, Engels et al. 1999, Asayama et al. 1999). The activity of peroxisomal beta-oxidation was increased in liver of diabetic animals in both alloxan- and streptozotocin-induced diabetes mellitus. It is known that the changes of activities of peroxisomal enzymes in the case of peroxisomal proliferation are not uniform when different peroxisomal proliferators are used. This 
different induction of peroxisomal enzymes lead us to study the activities of peroxisomal enzymes other than enzymes of beta-oxidation in animals with experimental streptozotocin diabetes.

There are four different peroxisomal compartments - peroxisomal core with urate oxidase, peroxisomal matrix, peroxisomal membranes and compartment with D-amino acid oxidase activity (Chandoga and Petrovič 2001). We analyzed the activities of peroxisomal enzymes from three different peroxisomal compartments - NADP-dependent isocitrate dehydrogenase, L-hydroxy acid oxidase and catalase from peroxisomal matrix, NADH-cytochrome $b_{5}$ reductase from peroxisomal membranes and D-amino acid oxidase from its own compartment. The results of our experiments showed that there were no significant changes in the activities of liver catalase, DAOX and NADH-cytochrome $b_{5}$ reductase, but the activities of GOX and NADP-ICDH were significantly decreased. The discrepancy between published increase of activities of enzymes of peroxisomal beta-oxidation and our results which showed decreased activities of peroxisomal GOX and NADP-ICDH and not significant changes of activities of catalase, DAOX and NADH-cytochrome $b_{5}$ reductase suggests that diabetes mellitus influences peroxisomes and their enzymes by the different way.

Chandoga et al. (1994a,b) described similar difference between changes of activities of enzymes of peroxisomal beta-oxidation and DAOX. Clofibric acid increased the activity of peroxisomal acetyl-carnitine transferase and palmitoyl-CoA oxidase and decreased the activity of DAOX and GOX. Asayama et al. (1999) suggested that the increased supply of fatty acids to liver in diabetic state stimulates the expression of PPAR-alpha and its target genes responsible for the beta-oxidation of fatty acids. But it is very probable that there are also other factors which can participate in the process of induction and/or repression of peroxisomal enzymes. One of these factors is the increased oxidative stress which is present in diabetes mellitus. The metabolic alterations that accompany diabetes can affect prooxidant/antioxidant balance in several ways. One of the important antioxidant enzymes is catalase. Catalase is a haem-containing ubiquitous enzyme, in eukaryotes it is found in peroxisomes. The enzyme probably serves to degrade hydrogen peroxide produced by peroxisomal oxidases to water and oxygen. Observations regarding catalase activity in the tissues of diabetic animals are rather controversial. The activity of catalase in the liver and kidneys of diabetic animals is generally believed to decrease (Rajarajeswari and Pari 2011, Lucchesi et al. 2013, Singh et al. 2013) although there are also reports of its increase (Kakkar et al. 1995, Cho et al. 2002). The activity of liver catalase in diabetic animals in our study was not significantly changed in comparison with control group. Similarly no changes in activity of liver catalase in diabetic rats described also Aliciguzel et al. (2003) and Maritim et al. (2003). These discrepancies in results of liver catalase in diabetes mellitus may be partly explained by the variability in the diabetes models used including the strain and sex of the animals, their age at the induction of diabetes, the severity of the resulting insulin deficiency, and the duration of diabetes.

The determination of the activity of GOX in liver of our experimental animal showed significantly decreased values in comparison with control group. Decrease of the activity of liver peroxisomal GOX could be in connection with increased oxidative stress in diabetes mellitus. Recalcati et al. (2003) described oxidative stress-mediated down-regulation of rat glycolate oxidase. Down-regulation of GOX expression during oxidative stress may provide a mechanism to prevent excessive hydrogen peroxide formation in liver peroxisomes and may represent the prototype of poorly recognized but potentially relevant response to oxidative injury involving down-regulation of reactive oxygen species producing enzymes. Increase in production of reactive oxygen species due to increased activity of oxidases of peroxisomal beta-oxidation in diabetic animals could compensatory decrease the activity of some other peroxisomal enzymes in the liver of diabetic animals.

The decrease of activity of NADP-ICDH is interesting also in connection with increased lipid peroxidation in liver tissue, because NADP-ICDH is a source of reduced NADPH which is important for normal function of glutathione peroxidase which participates on detoxification of lipid peroxides.

In summary, we have shown that diabetes mellitus influenced peroxisomal enzymes by the different way. In despite of well-known induction of peroxisomal beta-oxidation, the activities of catalase, DAOX and NADH-cytochrome $b_{5}$ reductase were not significantly changed and the activities of GOX and NADP-dependent ICDH were significantly decreased. The effect of diabetes on liver peroxisomes is probably due to the increased supply of fatty acids to liver in diabetic state and also due to increased oxidative stress. The changes of metabolic 
activity of peroxisomal compartment may participate on the development of diabetic fatty liver disease.

\section{Conflict of Interest}

There is no conflict of interest.

\section{Acknowledgements}

The authors wish express their appreciation to
E. Hederová for her technical assistance. This study was supported by grant VEGA 1/0962/12.

\section{Abbreviations}

DAOX, D-amino acid oxidase; GOX, glycolate oxidase, L-hydroxy acid oxidase; ICDH, isocitrate dehydrogenase; NAFLD, non-alcoholic fatty liver disease; NASH, nonalcoholic steatohepatitis; ROS, reactive oxygen species

\section{References}

ALICIGUZEL Y, OZEN I, ASLAN M, KARAYALCIN U: Activities of xanthine oxidase and antioxidant enzymes in different tissues of diabetic rats. J Lab Clin Med 142: 172-177, 2003.

ASAYAMA K, SANDHIR R, SHEIKH FG, HAYASHIBE H, NAKANE T, SINGH I: Increased peroxisomal fatty acid beta-oxidation and enhanced expression of peroxisome proliferator-activated receptor-alpha in diabetic rat liver. Mol Cell Biochem 194: 227-234, 1999.

BAUDHUIN P, BEAUFAY H, RAHMAN-LI Y, SELLINGER OZ, WATTIAUX R, JACQUES P, DE DUVE C: Tissue fractionation studies. 17. Intracellular distribution of monoamine oxidase, aspartate aminotransferase, alanine aminotransferase, D-amino acid oxidase and catalase in rat liver tissue. Biochem J 92: 179-184, 1964.

BERNT E, BERGMEYER HU: Isocitrate dehydrogenase. In: Methods of Enzymatic Analysis, Vol. 2. HU BERGMEYER (ed), Verlag Chemie, Weinheim, 1974, pp 624-631.

BOVERIS A, OSHINO M, CHANCE B: The cellular production of hydrogen peroxide. Biochem J 128: 617-630, 1972.

CHANDOGA J: Properties and biogenesis of peroxisomes. Bratisl Lek Listy 95: 543-557, 1994.

CHANDOGA J, PETROVIČ R: Peroxisomes - features, biogenesis and regulation of the peroxisome genes. (in Slovak) Cas Lek Cesk 140: 8-12, 2001.

CHANDOGA J, ROJEKOVÁ I, HAMPL L, HOCMAN G: Cetaben and fibrates both influence the activities of peroxisomal enzyme in different ways. Biochem Pharmacol 47: 515-519, 1994a.

CHANDOGA J, HAMPL L, TURECKÝ L, ROJEKOVÁ I, UHLÍKOVÁ E, HOCMAN G: Cetaben is an exceptional type of peroxisome proliferator. Int J Biochem 26: 679-696, $1994 \mathrm{~b}$.

CHO SY, PARK JY, PARK EM, CHOI MS, LEE MK, JEON SM, JANG MK, KIM MJ, PARK YB: Alteration of hepatic antioxidant enzyme activities and lipid profile in streptozotocin-induced diabetic rats by supplementation of dandelion water extract. Clin Chim Acta 317: 109-117, 2002.

DAY CP, JAMES OFW: Steatohepatitis - a tale of two "hits"? Gastroenterology 114: 842-845, 1998.

DELLILE HK, BONEKAMP NA, SCHRADER M: Peroxisomes and disease - an overview. Int J Biomed Sci 2: 308$314,2006$.

DERKACH KV, MOYSEYUK IV, CHISTYAKOVA OV, SHPAKOV AO: Androgen deficiency in male rats with prolonged neonatal streptozotocin diabetes. Bull Exp Biol Med 155: 339-342, 2013.

DEVASAGAYAM TP: Lipid peroxidation in rat uterus. Biochim Biophys Acta 876: 507-514, 1986.

DEVASAGAYAM TP, TARACHAND U: Pregnancy-associated decrease in lipid peroxidation in rat liver. Biochem Int 16: 45-52, 1988.

DIEHL AM: Endotoxins and cytokines in the pathogenesis of non-alcoholic steatohepatitis. In: Steatohepatitis. U LEUSCHNER, O JAMES, H DANCYGIER (eds), Kluwer Academic Publishers, Dordrecht, 2000, pp 6268.

ENGELS W, VAN BILSEN M, WOLFFENBUTTEL BH, VAN DER VUSSE GJ, GLATZ JF: Cytochrome P450, peroxisome proliferation and cytoplasmic fatty acid-binding protein content in liver, heart and kidney of the diabetic rat. Mol Cell Biochem 192: 53-61, 1999.

ISLAM MS, LOOTS DU T: Experimental rodent models of type 2 diabetes: a review. Methods Find Exp Clin Pharmacol 31: 249-261, 2009. 
IWASE M: A new animal model of non-insulin-dependent diabetes mellitus with hypertension: neonatal streptozotocin treatment in spontaneously hypertensive rats. Fukuoka Igaku Zasshi 82: 415-427, 1991.

JAMES OFW: Diagnosis of non-alcoholic steatohepatitis. In: Steatohepatitis. U LEUSCHNER, O JAMES, H DANCYGIER (eds), Kluwer Academic Publishers, Dordrecht, 2000, pp 34-39.

JOHNSON RN, METCALF PA, BAKER JR: Fructosamine: a new approach to the estimation of serum glycosylprotein. An index of diabetic control. Clin Chim Acta 127: 87-95, 1982.

KAKKAR R, KALRA J, MANTHA SV, PRASAD K: Lipid peroxidation and activity of antioxidant enzymes in diabetic rats. Mol Cell Biochem 151: 113-119, 1995.

KAYA-DAGISTANLI F, OZTURK M: The role of clusterin on pancreatic beta cell regeneration after exendin-4 treatment in neonatal streptozotocin administrated rats. Acta Histochem 115: 577-586, 2013.

LOWRY OH, ROSENBROUGH NJ, FARR AL, RANDALL RJ: Protein measurement with Folin phenol reagent. J Biol Chem 193: 265-275, 1951.

LUCCHESI AN, FREITAS NT, CASSETTARI LL, MARQUES SF, SPADELLA CT: Diabetes mellitus triggers oxidative stress in the liver of alloxan-treated rats. A mechanism for diabetic chronic liver disease. Acta Cir Bras 28: 502-508, 2013.

MARCHESINI G, BRIZI M, MORSELLI-LABATE AM, BIANCHI G, BUGIANESI E, MCCULLOUGH AJ, FORLANI G, MELCHIONDA N: Association of nonalcoholic fatty liver disease with insulin resistance. Am J Med 107: 450-455, 1999.

MARITIM AC, SANDERS RA, WATKINS JB: Effects of alpha-lipoic acid on biomarkers of oxidative stress in streptozotocin-induced diabetic rats. J Nutr Biochem 14: 288-294, 2003.

MATTEONI CA, YOUNOSSI ZM, GRAMLICH T, BOPARAI N, LIU YC, MCCULLOUGH AJ: Nonalcoholic fatty liver disease: a spectrum of clinical pathological severity. Gastroenterology 116: 1413-1419, 1999.

MIHARA K, SATO R: Detergent-solubilized NADH-cytochrome $b_{5}$ reductase. In: Methods in Enzymology, Vol. 52. SP COLOWICK, NO KAPLAN (eds), Academic Press, New York, 1978, pp 102-108.

NIEDERLAND TR, GVOZDJÁK J, TRIZNOVÁ M: The determination of glycogen in tissues. (in Slovak) Bratisl Lek Listy 36: 95-103, 1956.

PORTHA B, GIROIX MH, KERGOAT M, BAILBE D, BLONDEL O, SERRADAS P: Animal models of non-insulindependent diabetes induced in the rat by experimental reduction of B cell mass. Journ Annu Diabetol Hotel Dieu: 33-46, 1988.

RAJARAJESWARI N, PARI L: Antioxidant role of coumarin on streptozotocin-nicotinamide-induced type 2 diabetic rats. J Biochem Mol Toxicol 25: 355-361, 2011.

RECALCATI S, TACCHINI L, ALBERGHINI A, CONTE D, CAIRO G: Oxidative stress-mediated down-regulation of rat hydroxyacid oxidase 1, a liver-specific peroxisomal enzyme. Hepatology 38: 1159-1166, 2003.

SHARMA AK, RAIKWAR SK, KURMI MK, SRINIVASAN BP: Gemfibrozil and its combination with metformin on pleiotropic effect on IL-10 and adiponectin and anti-atherogenic treatment in insulin resistant type 2 diabetes mellitus rats. Inflammopharmacology 21: 137-145, 2013.

SINGH R, BHARDWAJ P, SHARMA P: Antioxidant and toxicological evaluation of Cassia sophera in streptozotocininduced diabetic Wistar rats. Pharmacognosy Res 5: 225-232, 2013.

SINHA AK: Colorimetric assay of catalase. Anal Biochem 47: 389-394, 1972.

THOMAS H, SCHLADT L, KNEHR M, OESCH F: Effect of diabetes and starvation on the activity of rat liver epoxide hydrolases, glutathione S-transferases and peroxisomal beta-oxidation. Biochem Pharmacol 38: 4291-4297, 1989.

TURECKÝ L, KUPČOVÁ V, MOJTO V, SMUTNÝ M, UHLÍKOVÁ E, VOZÁR I: Serum cholinesterase activity and proteosynthetic function of the liver in patients with diabetes mellitus. Bratisl Lek Listy 106: 266-269, 2005. 